\title{
ОЦЕНКА МУТАГЕННОЙ АКТИВНОСТИ ЛЕКАРСТВЕННОГО СРЕДСТВА, СНИЖАЮЩЕГО ГЕЛИКОБАКТЕРОПОДОБНЫЕ ПОВРЕЖДЕНИЯ, НА ОСНОВЕ ПРОИЗВОДНОГО БЕНЗИМИДАЗОЛА
}

\author{
С.С. Сурин', Г.Л. Снигур ${ }^{1}$, Д.А. Кавалерова', М.В. Черников²
}

\author{
${ }^{1}$ Кафедра биологии ФГБОУ ВО ВолгГМУ Минздрава России, \\ 400131 Российская Федерация Волгоград, площадь Павших Борцов 1. \\ ${ }^{2}$ Кафедра фармакологии с курсом клинической фармакологии \\ Пятигорский медико-фармацевтический институт - филиал ФГБОУ ВО ВолгГМУ \\ 357532, Россия, Ставропольский край, г. Пятигорск, пр. Калинина, 11.
}

DOI: 10.19163/MedChemRussia2021-2021-490

Email:dareznikova@yandex.ru

Целью работы являлось определение мутагенного потенциала фармацевтической субстанции (ФС) динитрат 2-фенил-9-диэтиламиноэтилимидазо[1,2-а] бензимидазола на индукцию генных мутаций в тесте invitro и на индукцию хромосомных повреждений invivo.

В тесте на индукцию генных мутаций (тест Эймса) изучалась ФС в концентрациях 5 мг/мл, 2,5 мг/мл, 1,25 мг/мл, 0,625 мг/мл, 0,3125 мг/мл и 0,15625 мг/мл. Для выявления мутагенного потенциала с и без метаболической активации фракцией S9 печени были использованы S.typhimurium TA98, TA100, TA1535, TA1537 и E.coli WP2 uvrA + WP2 [рKM101] для регистрации мутаций по типу замены пар оснований и сдвига рамки считывания [2]. Цитогенетическое исследование на индукцию хромосомных аберраций в клетках костного мозга мышей было проведено в двух сериях: однократное введение ФС (самцы в терапевтической - 24 мг/кг, и субтоксической дозах (58 мг/кг) и курсовое введение ФС (самцы и самки в терапевтической дозе - 24 мг/кг). Положительным контролем был мутаген (циклофосфамид - 20 мг/кг), в качестве отрицательного контроля вводилась дистиллированная вода [1].

В тесте Эймса под действием ФС по сравнению с негативным контролем не происходило статистически значимого увеличения ревертантных колоний, что свидетельствует об отсутствии мутагенной активности тестируемых образцов. В цитогенетическом исследовании при введении ФС в терапевтической и субтоксической дозах не выявлялось значимого увеличения уровня хромосомных аберраций. Результаты исследования по влиянию ФС на индукцию генных мутаций в тесте Эймса и хромосомных аберраций в цитогенетическом тесте могут свидетельствовать об отсутствии мутагенной активности у лекарственного средстваснижающего геликобактероподобные повреждения, на основе производного бензимидазола.

\section{Литература:}

[1].А.Н.Миронов, руководство по проведению доклинических исследований лекарственных средств. Часть первая-М: Гриф и К, 2012. -С.80-93.

[2]. Ames MPFTM Penta I Xenometrix, Швейцария, Инструкция по применению теста Эймса в микропланшетном формате версия набора с полутвердыми стоками штаммов. Версия 4.5_S, 2012, 37 с. 